In cooperation with the Berks County Conservancy

\title{
Occurrence of Bacteria in Blue Marsh Lake and Selected Tributaries, Berks County, Pennsylvania: September-October 2001
}

The Commonwealth of Pennsylvania has water-quality standards that limit the number of specific bacteria in water that is considered safe for recreational use. Bacteria such as fecal streptococci, fecal coliforms, and Escherichia coli (E. coli) are used to assess recreational water quality because they usually live in the intestines of warm-blooded animals. Fecal indicator bacteria commonly are associated with waterborne disease-causing organisms (pathogens). These indicator bacteria are used routinely as a measure of the quality of water for recreational activities such as swimming, boating, and water skiing. If the indicator bacteria are present, effective measures could be taken to prevent the transmission or epidemic outbreak of waterborne diseases as a result of contamination of these waters from human or animal waste.

Blue Marsh Lake (fig. 1) is on Tulpehocken Creek in Berks County, $\mathrm{Pa}$., and drains a largely agricultural basin. Land use in the basin is approximately 60 percent cropland, and 85 percent of the farms are livestock and poultry farms (U.S. Department of Agriculture and others, 1997).

The potential sources of fecal bacteria are:

- geese that inhabit the recreational areas of the lake,

- humans that visit the Dry Brooks Day Use Area (swimming area), and

- farm animals, wastewater facilities, and household septic systems in the basin (bacteria from these sources could enter the lake through tributaries).

To meet the recreational water-quality standard, lake water may not have more than 200 colony-forming units (CFU) of fecal coliforms per 100 milliliters (mL). During the week of July 23, 2001, data collected by the U.S. Army Corps of Engineers (USACE) at the swimming area at Blue Marsh Lake showed concentrations of fecal coliforms in the water exceeding the standard (fig. 2) (U.S. Army Corps of Engineers, written commun., 2001). To determine the extent of elevated concentrations of fecal indicator bacteria, further study of the lake and selected tributaries was needed.

\section{HOW WAS THIS STUDY DONE?}

In fall 2001, the U.S. Geological Survey (USGS) and the Pennsylvania State University, in cooperation with Berks County Conservancy and in collaboration with USACE, investigated potential sources of fecal contamination at Blue Marsh Lake. A brief summary of the bacterial occurrence in Blue Marsh Lake and selected tributaries from this study is presented here. The sampling was designed to allow comparisons between bacterial concentration in tributaries to bacterial concentrations in the lake. The complete results of the study are published in Zimmerman and others (2002).

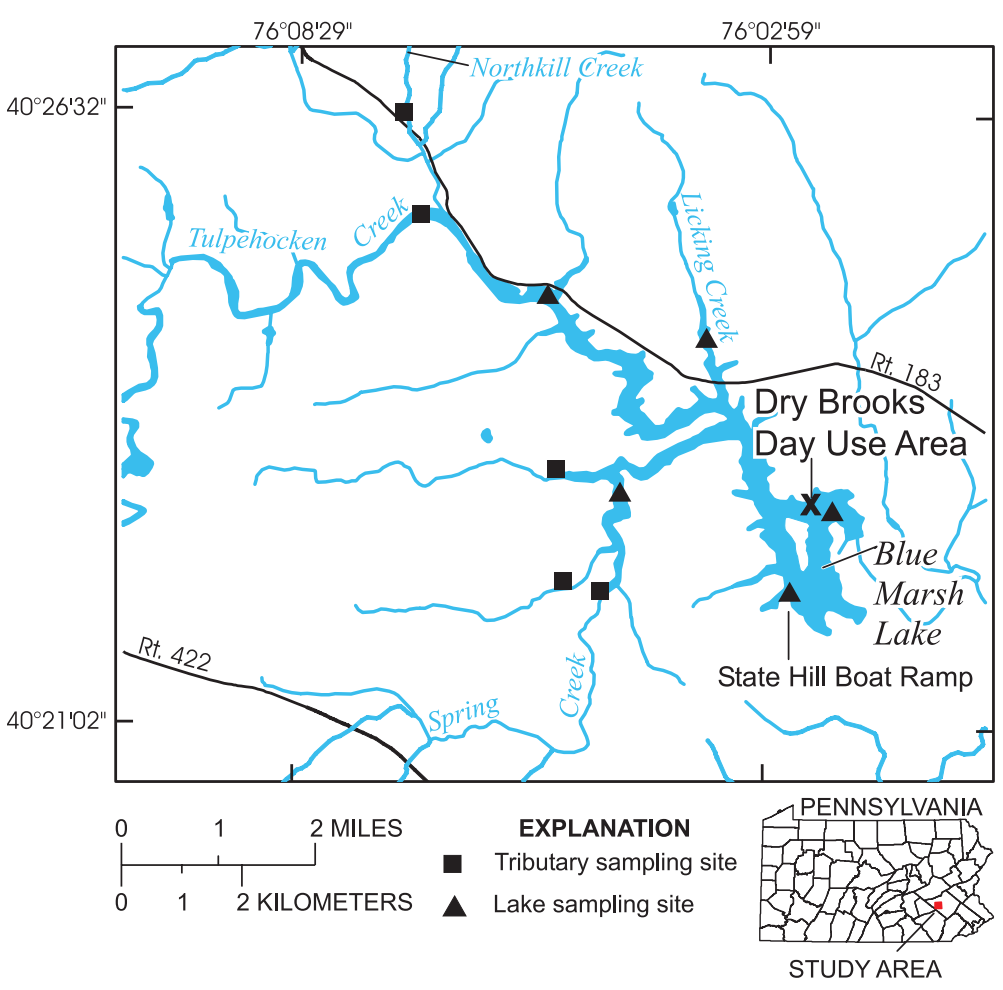

Figure 1. Location of Blue Marsh Lake and sampling sites.

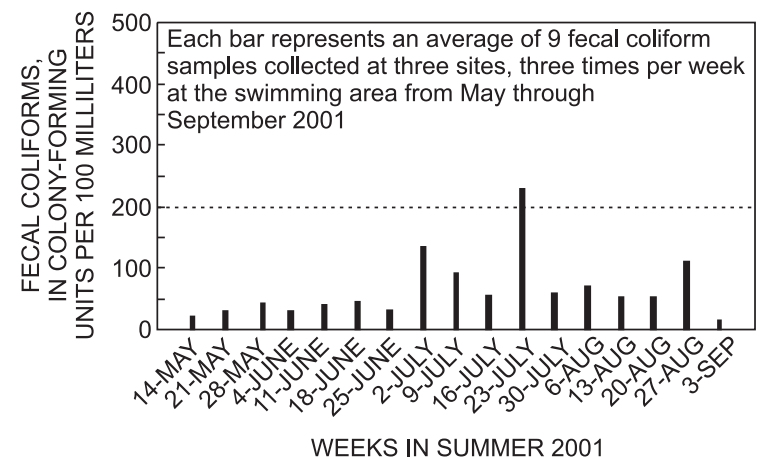

Figure 2. Average fecal coliform concentrations in Dry Brooks Day Use Area at Blue Marsh Lake, May-September 2001 (U.S. Army Corps of Engineers, written commun., 2001). Concentrations were determined using standard methods. Concentrations are expressed as colony-forming units (CFU). Generally, $1 \mathrm{CFU}=1$ cell. The dashed line at $200 \mathrm{CFU}$ represents the recreational water-quality standard for Pennsylvania. 
Fecal indicator bacteria were measured during stormflow (September 20, 2001) and base-flow conditions (October 11 and 12, 2001) at six lake sites and at five of the major perennial tributaries that flow into the lake. Bacteria concentrations also were measured in the beach sand at three locations at the swimming area. The lake sites consisted of the inflow areas at the mouths of Spring, Licking, and Tulpehocken Creeks, near the State Hill Boat Ramp, in the body of the lake, and in the swimming area. Tulpehocken, Northkill, and Spring Creeks and two unnamed tributaries to the lake were sampled. The three sand samples collected at the swimming area were from the upper part of the beach, the sand/water interface, and the lower part of the beach. The methods used for field sampling and laboratory analysis are described in Zimmerman and others (2002).

\section{WHAT WERE THE STUDY RESULTS?}

The data show elevated concentrations of the indicator bacteria in the sand at the swimming area and in the tributaries (fig. 3). The sand had the highest concentrations of fecal indicator bacteria during the storm event; the average concentration of fecal indicator bacteria was about 30,000,000 CFU per $100 \mathrm{~mL}$. Although the concentrations were lower during the base-flow sampling, the average was still about $10,000 \mathrm{CFU}$ per $100 \mathrm{~mL}$. During base-flow conditions, there were significantly more indicator bacteria in the sand than in the water at the swimming area. These data indicate that the sand likely contributes fecal coliforms to the water at the swimming area particularly under storm conditions.

During stormflow, there were much higher numbers of fecal bacteria in the tributaries than in the lake. The bacteria concentrations sharply declined from the tributary sampling sites to the lake sampling sites. This indicates that the concentrations of bacteria in the tributaries are diluted or die off as they enter the lake, and the tributaries may not be the source of fecal bacteria contamination at the swimming area.

The resident geese apparently contribute to the fecal bacteria contamination at the swimming area. The sand, in both the dry and submerged areas, was littered with goose feces. This not only renders the Dry Brooks Day Use Area aesthetically undesirable, but it also poses a potential public health concern because of the high concentrations of fecal indicator bacteria in the sand.

\section{-Michele L. Zimmerman}

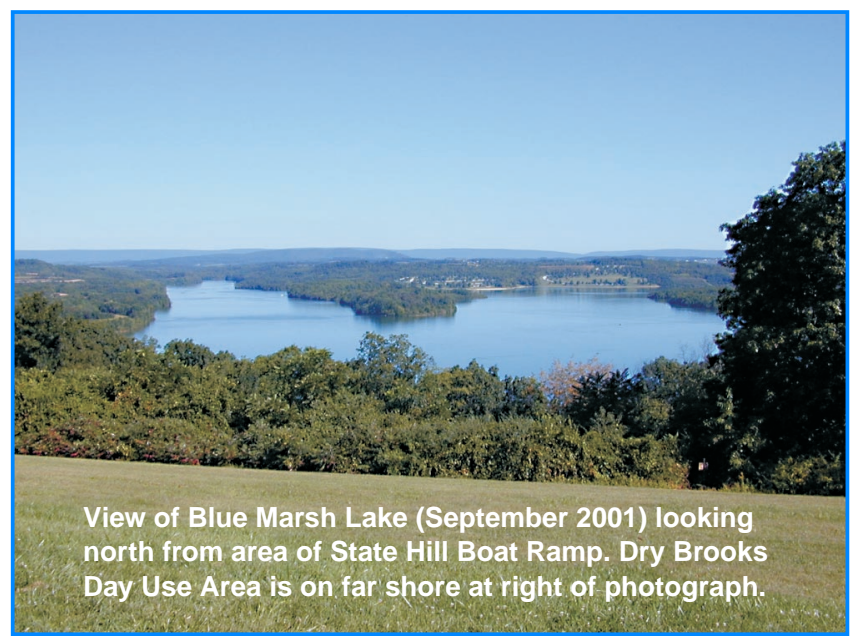

\section{REFERENCES CITED}

U.S. Department of Agriculture, Berks County Conservancy, Berks County Conservation District, Lebanon County Conservation District (partners), 1997, Tulpehocken Creek (Berks County, Pa., and Lebanon County, Pa.) final watershed protection plan and environmental assessment: Reading, $\mathrm{Pa}$. [variously paginated].

Zimmerman, M.L., Bonham, M.J., and Baker, K.H., 2002, Bacteria occurrence in Blue Marsh Lake and selected tributaries-Survey results from September and October 2001: Middletown, Pa., Penn State Harrisburg Environmental Microbiology Research Laboratory Technical Report Series 1, $28 \mathrm{p}$.

WHERE DO I GET ADDITIONAL INFORMATION?

\section{USGS Water-Quality Projects}

\section{Contact: District Chief}

U.S. Geological Survey, WRD

215 Limekiln Road

New Cumberland, PA 17070

Phone: (717) 730-6912

http://pa.water.usgs.gov

\section{Watershed Information:}

Contact: Joseph Hoffman, Program Director Berks County Conservancy 25 North 11th Street Reading, PA 19601

Phone: (610) 372-4992 ext. 105

http://www.berks-conservancy.org 